\title{
Archaeoparasitological Analysis of Samples from the Cultural Layer of Nadym Gorodok dated Back to the 14th-Late 18th Centuries
}

\author{
Sergey Mikhailovich Slepchenko, 1,2,3,*, Oleg Viktorovich Kardash ${ }^{2,4}$, Vyacheslav Sergeyevich Slavinsky ${ }^{5}$, \\ Sergey Nikolaevich Ivanov', Rakultseva Daria Sergeyevna', Alexander Alekseevich Tsybankov ${ }^{5}$, Dong Hoon Shin ${ }^{6}$ \\ 'Tyumen Scientific Center, Siberian Branch of the Russian Academy of Sciences, 86 Malygina Street, Tyumen 625003, Russian Federation; ${ }^{2}$ Surgut \\ State University, 1 Lenin Avenue, Surgut 628412, Russian Federation; ${ }^{2}$ Ltd Paleopoisk, 23/5 Demakova Street, Novosibirsk 630128, Russian \\ Federation; ${ }^{4}$ Autonomous Non-profit Organization the Institute of Archeology of the North, 16 Naberezhnaya Street, Nefteyugansk 628305, Russian \\ Federation; ${ }^{5}$ nstitute of Archaeology and Ethnography Siberian Branch of the Russian Academy of Sciences, 17, Acad. Lavretiev Avenue, \\ Novosibirsk 630090, Russian Federation; 'aboratory of Bioanthropology, Paleopathology and History of Diseases, Institute of Forensic Science/ \\ Department of Anatomy, Seoul National University College of Medicine, Seoul 03080, Korea
}

\begin{abstract}
An archaeoparasitological analysis of the soil samples from Nadym Gorodok site of Western Siberia has been carried out in this study. The archaeological site was dated as the 13 to 18 th century, being characterized as permafrost region ensuring good preservation of ancient parasite eggs. Parasite eggs as Opisthorchis felineus, Alaria alata, and Diphyllobothrium sp. were found in the archaeological soil samples, which made clear about the detailed aspects of Nadym Gorodok people's life. We found the Diphyllobothrium sp. eggs throughout the 14 to 18th century specimens, allowing us to presume that raw or undercooked fish might have been commonly used for the foods of Nadym Gorodok inhabitants and their dogs for at least the past 400 years. Our study on Nadym Gorodok specimens also demonstrate that there might have been migratory interactions and strong economic ties between the people and society in Western Siberia, based on archaeoparasitological results of Opisthorchis felineus in Western Siberia.
\end{abstract}

Key words: Alaria alata, Opisthorchis felineus, Diphyllobothrium sp. archaeoparasitology, paleoparasitology, archaeology, Middle Age, North Asia, Nadym Gorodok

\section{INTRODUCTION}

Archaeoparasitology is an interdisciplinary research field between parasitology, archaeology and other disciplines such as physical anthropology and ethnography etc. [1]. Coprolites, ancient or medieval mummies' intestinal contents, and soil sediment specimens precipitated on the sacrum are the objects commonly used for archaeoparasitological research [2,3]. Among these, archaeologically obtained soil sediments have been repeatedly used for exploring the sanitary conditions of different settlements, thus revealing the risk factors of parasitic infections among peoples in history [4-9].

Recently, the ancient population of Western Siberia has been

- Received 24 August 2019, revised 17 September 2019, accepted 23 September 2019. *Corresponding author (s_slepchenko@list.ru)

(c) 2019, Korean Society for Parasitology and Tropical Medicine

This is an Open Access article distributed under the terms of the Creative Commons Attribution Non-Commercial License (http://creativecommons.org/licenses/by-nc/4.0) which permits unrestricted non-commercial use, distribution, and reproduction in any medium, provided the original work is properly cited. studied by archaeoparasitological methods as well [10]. The specimens of various human populations, those living in modern as well as historical societies, have been examined by archaeoparasitologists thus far [11-13]. Especially, parasitological studies on the arctic or subarctic areas of Western Siberia in history have been performed using soil sediment specimens taken from the buried people's sacrum surface, intestinal contents of mummies or coprolites of animals $[11,12,14,15]$.

In spite of the previous achievements, we note that the cultural layer sediment specimens obtained by the excavations of Siberian indigenous people's settlement ruins have not been examined and reported sufficiently so far. This report is thus aimed to conjecture the parasite infection pattern, the changes in dietary habit, and the details about contacts and migrations of West Siberian people, based on archaeoparasitological study on the soil specimens of various historical periods, found in the settlement ruins in Nadym Gorodok, Russia. 


\section{MATERIALS AND METHODS}

\section{Archaeological context}

Nadym Gorodok is located in the forest-tundra transition zone of West Siberia, around the Nadym River estuary $\left(66^{\circ}\right.$ $03^{\prime}, 72^{\circ} 00^{\prime}$ ). This archaeological site is a permafrost layer that does not thaw even during summer, ensuring good preservation status of parasitological specimens in the archaeological sites [16]. It was a locality that had been inhabited by the Siberian indigenous population, thus having functioned as a settlement of the ancestors of the Nenets and Northern Khanty from the 13 to 18 th century [16] (Fig. 1). It is confirmed that during the final period of its functioning as settlement, i.e. from the late 16th to the first third of the 18th centuries, Nadym Gorodok was a territorial military-political center consisted of several communities in Yamal Peninsula and Ob Bay southern coast in the lower reaches of $\mathrm{Ob}$ and Nadym Rivers. It was also a winter residence for the elite leaders of Bolshaia Karacheia, the tribal association of the Nenets.

Archaeologically speaking, the planning pattern of the defense-residential complex (DRC) of Nadym Gorodok was

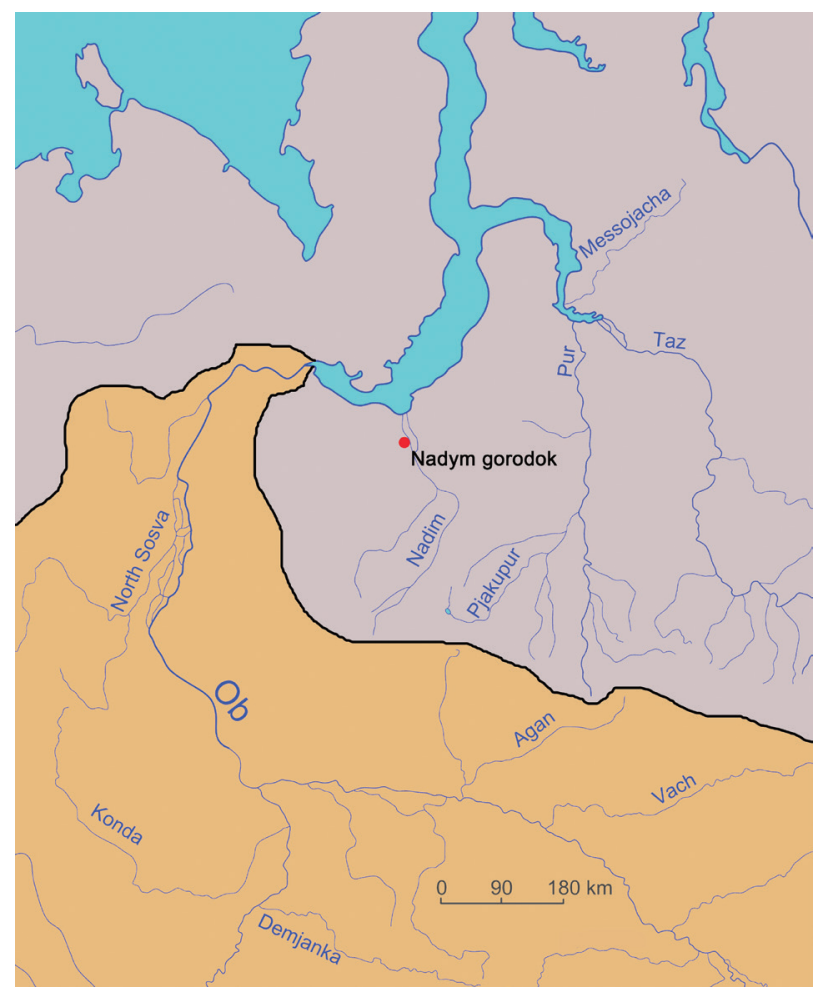

Fig. 1. Location of the archaeological site Nadym gorodok. Orange color shows the distribution area of Opisthorchis felineus and Gray color indicates the absence of Opisthorchis felineus. comprised of 6 symmetric quarters with the buildings of different architectural traditions, reflecting the heterogeneous ethnic origin of the population) [16]. By the reconstruction of DRC in the mid-15th to mid-16th century Nadym Gorodok, the archaeologists found rectangular-shaped construction, formed by a loose-fill outside wall along the perimeter in which 2 entrances fortified by log towers could be located [16]. The general scheme of Nadym Gorodok is analogous to the structure of the late 16-18th century Russian stockade towns in Northwestern Siberia.

The Nenets and Northern Khanty in Nadym Gorodok [16] seem to have done fishing, hunting and dog breeding, which has been already confirmed by previous archaeological anthropological reports [17]. Meanwhile, no signs of reindeer breeding have been found at the place [18]. The cultural heritage concerning the materials found at the site is not simple, but is heterogeneous. Although they represent Slavic-Russian origin, some objects also show the tradition of the ancient indigenous population in the area [16].

\section{Sample collection}

Stationary excavations at Nadym Gorodok were carried out in 1998 to 2016. Samples were collected from chronologically and stratographically different layers in various areas of the settlement complex, covering the entire period of Nadym Gorodok's existence. The dating of geological strata was estimated by dendrochronological as well as archaeological method. During excavations in 2001, 2003-2005, 2007, and 2016, 34 soil samples (up to $100 \mathrm{~g}$ each) were collected at Nadym Gorodok. The samples were cautiously collected to prevent outside contamination using the tools and containers separately prepared for each sample. The sample collection was conducted on various sites of Nadym Gorodok such as DRC and economic, multi-functional complex (EMC) present outside of DRC (Figs. 2, 3). We also collected soil samples outside the archaeological sites as a reference (negative control) sample. The soil samples were dried, packed in sealed plastic bags, and labeled it. The samples were finally transported to Tyumen Scientific Center for further work.

The soil samples (10 to $30 \mathrm{~g}$ ) were placed in Bunsen beakers in a laboratory setting, to which a $0.5 \%$ solution of trisodium phosphate $\left(\mathrm{Na}_{3} \mathrm{PO}_{4}\right)$ was added [19]. The supernatant was elutriated 3 times over a week, followed by sifting the residue through $200 \mu \mathrm{m}$ sieve. Sample separation was performed in centrifugal tubes. The residue was gathered using a multiple 


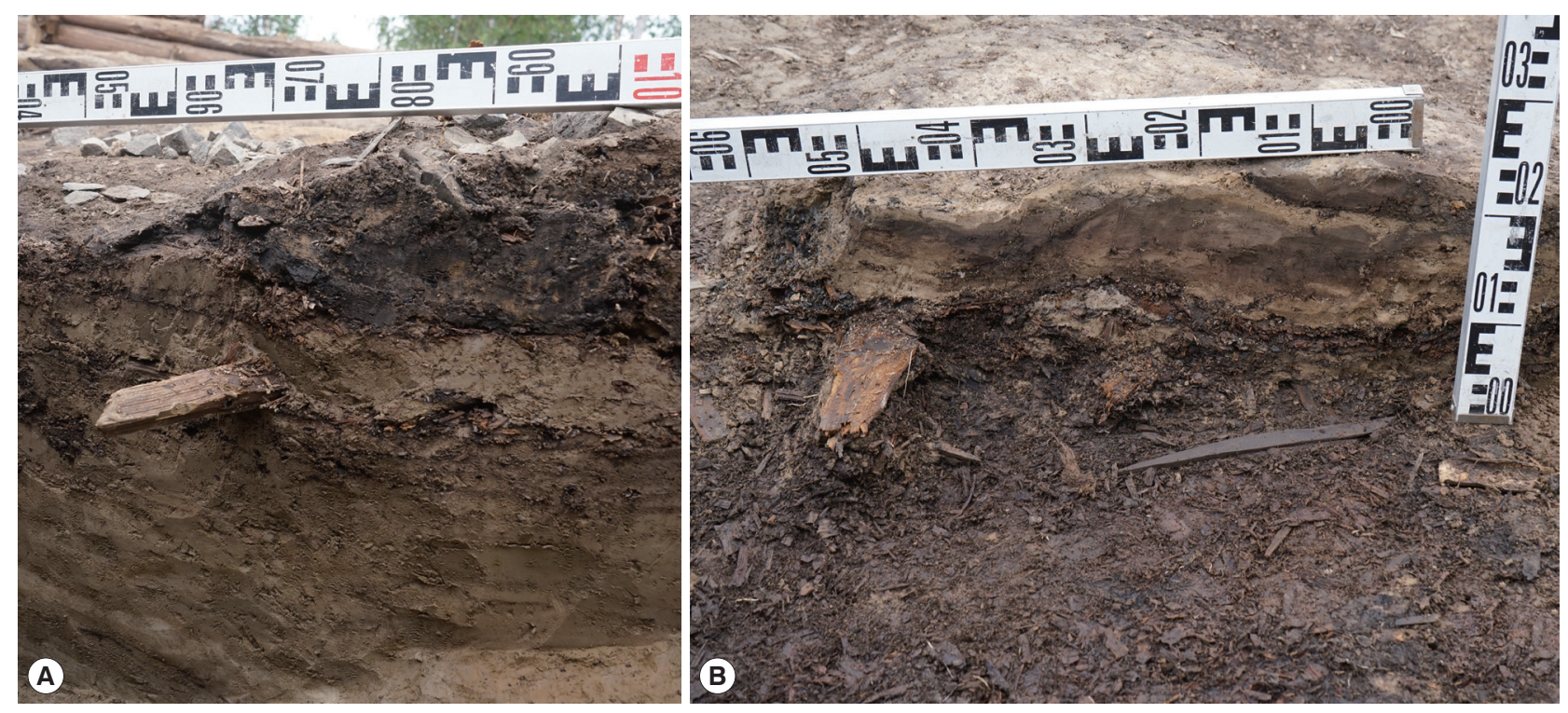

Fig. 2. A fragment of the cultural layers of the archaeological site of Nadym. (A) Vertical section. The photo shows chronologically different cultural layers. (B) Horizontal section. The cleared cultural layer from which samples were taken.
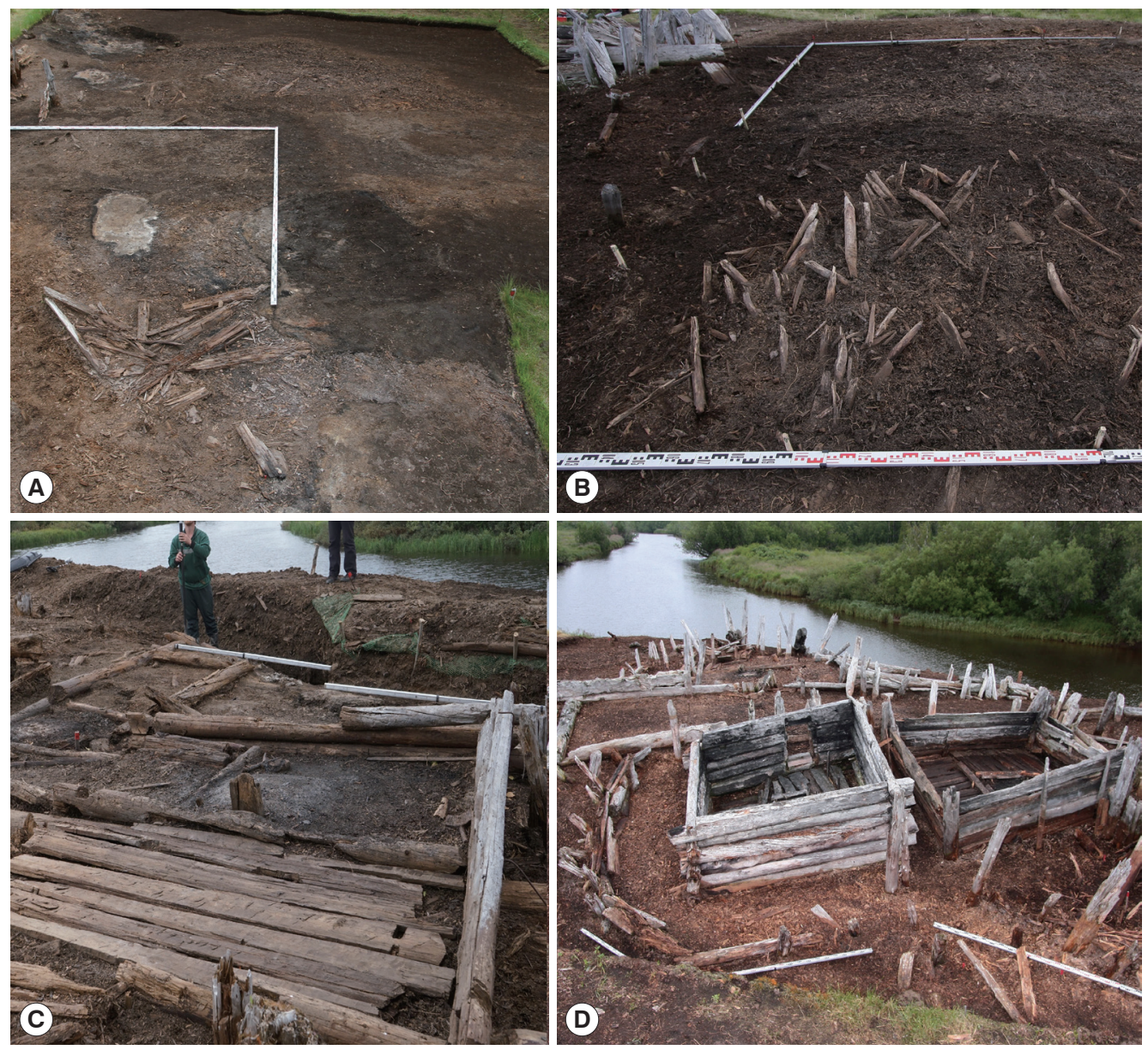

Fig. 3. The defense and residential complex (A,B) and economical, multifunctional complex (C,D). 
centrifuge process for $7 \mathrm{~min}$ at 1,500 rpm. After that, we added glycerin until it covered the samples. We stirred the residue and then warmed up the tubes in a water-bath at $80^{\circ} \mathrm{C}$ for 10 $\min$. The hot tubes were centrifuged again for $7 \mathrm{~min}$ at 1,500 $\mathrm{rpm}$. After glycerin and the remaining water were elutriated, microslides were examined for each sample using AxioLabA1 (Zeiss, Oberkochen, Germany). For measurement, Axio Vision 4.6 (Zeiss) were used. For statistical analysis, $\chi^{2}$ test with Yates correction was done. Excel software (Microsoft, Redmond, Washington) was used for statistical calculations.

\section{RESULTS}

We did not find any parasite eggs in reference, negative control sample, ruling out the possible contamination of parasite eggs from the outside. In the soil samples taken from Nadym Gorodok's cultural layer, 3 different species of helminth eggs were discovered (Fig. 4). First, some eggs are light brown, ovalshaped, with a "shell" (Fig. 2). There is a small knob opposite the cap on the other side of an egg. The average egg diameter is 66.1-37.8 $\mu \mathrm{m} \times 82.1-62.4 \mu \mathrm{m}$. Taking these findings into ac- count, the eggs look belong to the genus Diphyllobothrium sp. [20]. Eggs of this genus were found in every chronological layer (23 of 34 samples, 67.6\%) (Table 1).

The second type is the oval-shaped eggs with a light yellow shell. No operculum was found in any of them. A feebly marked fold was observed on some eggs in which the operculum is to be attached. There is a shell pin on the opposite side of an egg. The egg size ranges from 34.25 to $32.39 \mu \mathrm{m}$ in length and 24.5 to $18.01 \mu \mathrm{m}$ in width. By the morphology of the eggs, we assumed that they are Opisthorchis felineus trematode [20]. The eggs of this helminth were found mostly in of the 14 to 15 th or the 17th to 18 th century (4 of 34 samples, $11.8 \%$ ) (Table 1).

The third one is the oval-shaped egg with a light brown shell. Neither operculum nor shell pin was found in any egg of this type. The egg size ranges from 101.3 to $120.4 \mu \mathrm{m}$ in length and from 58.6 to $65.8 \mu \mathrm{m}$ in width. Taken together, we concluded that they belong to the genus Alaria alata trematode [21]. Parasites of this genus were found in 2 samples (5.9\%) of the 14 to 15 th century (Table 1).

Diphyllobothrium sp. and Opisthorchis felineus eggs were found
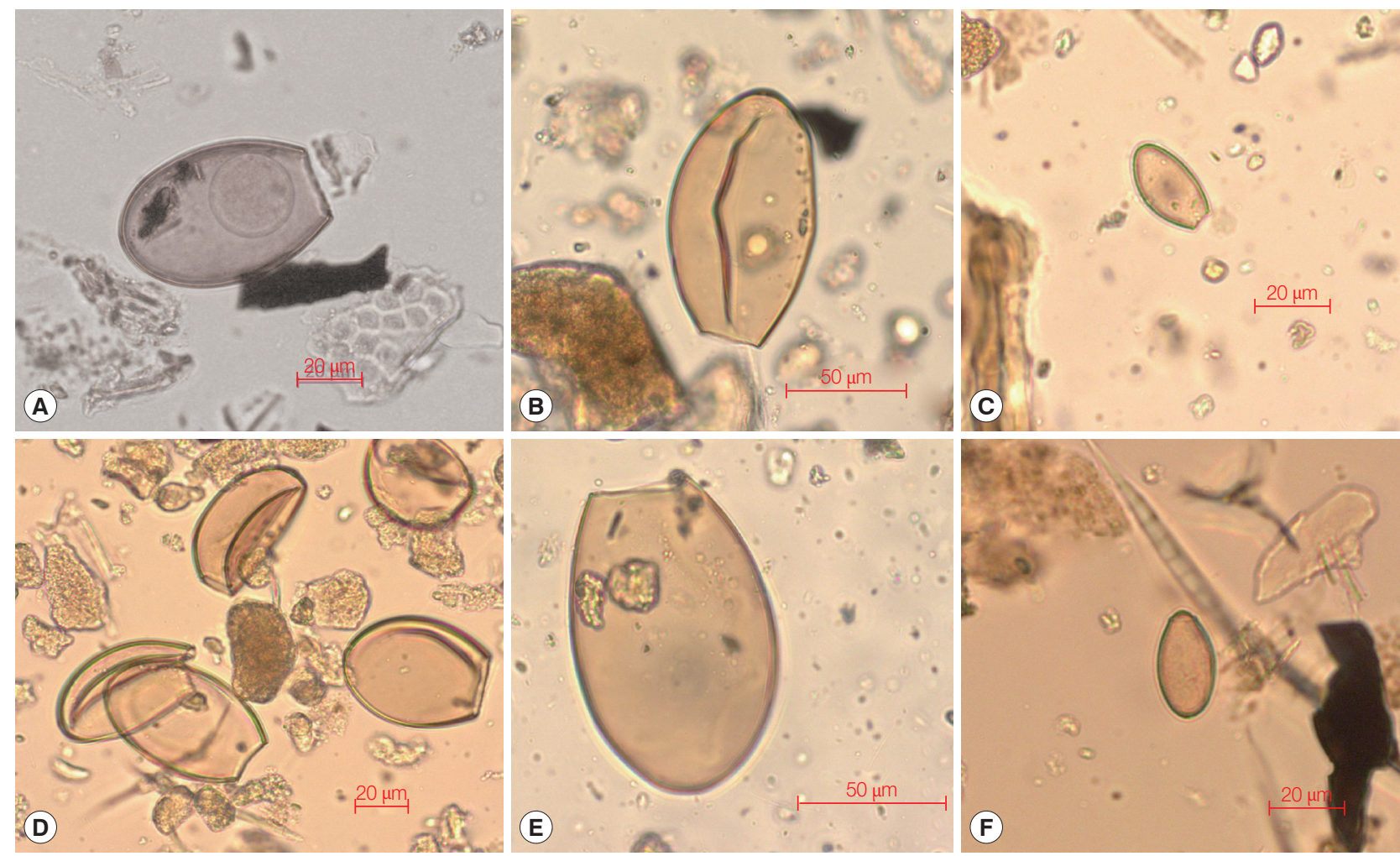

Fig. 4. Egg suggestive of Diphyllobothrium sp. eggs (A, D), Alaria alata eggs (B, E) and Opisthorchis felineus eggs (C, F). Found in soil samples from archaeological site Nadym gorodok. 
Table 1. Ancient parasite species observed in the specimen from the Cultural Layer of Nadym Gorodok site

\begin{tabular}{|c|c|c|c|}
\hline No. & & Species of parasites & Layer dating \\
\hline 1 & DRC & - & XIV century \\
\hline 2 & DRC & $\begin{array}{l}\text { Diphyllobothrium sp. } \\
\text { Opisthorchis felineus }\end{array}$ & XIV century \\
\hline 3 & DRC & Diphyllobothrium sp. & XIV-mid - XV centuries \\
\hline 4 & DRC & Diphyllobothrium sp. & XIV-mid - XV centuries \\
\hline 5 & DRC & Diphyllobothrium sp. & XIV-mid - XV centuries \\
\hline 6 & EMC & $\begin{array}{l}\text { Diphyllobothrium sp. } \\
\text { Opisthorchis felineus } \\
\text { Alaria alata }\end{array}$ & XIV-mid - XV centuries \\
\hline 7 & EMC & Diphyllobothrium sp. & XIV-mid - XV centuries \\
\hline 8 & EMC & & $X V$ century \\
\hline 9 & EMC & Diphyllobothrium sp. & $X V$ century \\
\hline 10 & EMC & Diphyllobothrium sp. & $X V$ century \\
\hline 11 & EMC & - & $X V$ century \\
\hline 12 & EMC & - & $\mathrm{XV}$-mid - XVI centuries \\
\hline 13 & EMC & Diphyllobothrium sp. & $\mathrm{XV}$-mid - XVI centuries \\
\hline 14 & EMC & Diphyllobothrium sp. & $\mathrm{XV}$-mid - XVI centuries \\
\hline 15 & EMC & Diphyllobothrium sp. & $\mathrm{XV}$-mid - XVI centuries \\
\hline 16 & EMC & Diphyllobothrium sp. & $\mathrm{XV}$-mid - XVI centuries \\
\hline 17 & EMC & - & $\mathrm{XV}$-mid - XVI centuries \\
\hline 18 & DRC & Diphyllobothrium sp. & XVI century \\
\hline 19 & DRC & & $\mathrm{XVI}$ century \\
\hline 20 & DRC & & XVI century \\
\hline 21 & DRC & & $\mathrm{XVI}$ century \\
\hline 22 & DRC & & $\mathrm{XVI}$ century \\
\hline 23 & DRC & & $\mathrm{XVI}$ century \\
\hline 24 & DRC & Diphyllobothrium sp. & early XVII century \\
\hline 25 & DRC & Diphyllobothrium sp. & early XVII century \\
\hline 26 & DRC & Diphyllobothrium sp. & early XVII century \\
\hline 27 & DRC & $\begin{array}{l}\text { Diphyllobothrium sp. } \\
\text { Opisthorchis felineus }\end{array}$ & mid XVII century \\
\hline 28 & DRC & Diphyllobothrium sp. & end of XVII century \\
\hline 29 & EMC & $\begin{array}{l}\text { Diphyllobothrium sp. } \\
\text { Opisthorchis felineus } \\
\text { Alaria alata }\end{array}$ & XVII century \\
\hline 30 & DRC & - & XVII-XVIII centuries \\
\hline 31 & DRC & $\begin{array}{l}\text { Diphyllobothrium sp. } \\
\text { Opisthorchis felineus }\end{array}$ & $\begin{array}{l}\text { end of XVII- beginning - } \\
\text { XVIII centuries }\end{array}$ \\
\hline 32 & EMC & Diphyllobothrium sp. & XVII- beginning - XVIII centuries \\
\hline 33 & EMC & Diphyllobothrium sp. & XVII- beginning - XVIII centuries \\
\hline 34 & EMC & Diphyllobothrium sp. & XVII- beginning - XVIII centuries \\
\hline
\end{tabular}

$\mathrm{DRC}$, The defense-residential complex; EMC, Economical, multifunctional complex (the outside of DRC).

in the DRC samples (11 of 18, 61\%). In case of EMC, Diphyllobothrium sp., Opisthorchis felineus trematode, and Alaria alata trematode eggs were found in 12 of 16 samples (75\%). No statistically significant differences were found in the positive ratio of parasite eggs $\left(\chi^{2}\right.$ Yates $\left.=0.138\right)$ between the samples of DRC and EMC sites.

\section{DISCUSSION}

In previous studies, Diphyllobothrium sp. and Opisthorchis felineus eggs were found in intestinal contents of mummies, animal coprolites, and soil samples precipitated upon the sacrum found in the graves [11-13]. Alaria alata eggs were reported from the study on the 17-18th century dog coprolites [15]. Diphyllobothrium sp. eggs were also found in the samples of the late medieval Russian town site found in Mangazeya [17].

As demonstrated by the current archaeoparasitological research (Table 1), a variety of parasites was found in the soil samples taken from Nadym Gorodok's cultural layer. The pattern of the discovered species is somewhat similar to the above datasets of ancient parasite eggs previously discovered at the West Siberian archaeological sites.

In this study, we must consider whether the parasite eggs we found were authentic ancient parasite eggs of human beings. Actually, the indigenous population of Western Siberia did not use toilets, as indicated by archeological and ethnographic data $[16,17]$. Dogs could have lived inside DRC but also wandered in EMC. Therefore, human and dog coprolites could have been distributed at either DRC or EMC. Meanwhile, considering that wild animals or birds could not have accessed into DRC buildings [16], the coprolites of wild animals or birds should have been spread only in EMC, but not in DRC. Therefore, we could narrow down the sources of parasite eggs found at DRC to those of humans or domesticated dogs. In case of EMC, however, the eggs of Diphyllobothrium sp., Opisthorchis felineus and Alaria alata could have been originated from human, domesticated dogs, wild animals (e.g., arctic fox etc.) or birds [16].

We also note that the difference of finding pattern was not observed in Diphyllobothrium sp. throughout the 14 to 18th century specimens. This means that for at least 400 years, raw or insufficiently cooked fishes were prevailed in the diets of Nadym Gorodok natives and their dogs.

Also interesting is about the finding pattern of Opisthorchis eggs. Opisthorchis felineus eggs found in Nadym Gorodok samples also have related with raw fish consumption. As is well known, the hyperendemic area of opisthorchiasis in Western Siberia is mostly confined to the territory around the Ob-Irtysh basin [22]. Meanwhile, the Nadym Gorodok is not the infection foci of opisthorchiasis because it lacks the environmental conditions adequate for Bithynia tentaculata, the intermediate hosts of Opisthorchis felineus [22] (Fig. 1). Therefore, people 
and dogs could not have suffered from opisthorchiasis in the territory of Nadym Gorodok. Therefore, at some time in history, the people of Nadym Gorodok might have moved from the Ob-Irtysh basin, the most likely candidate site of the infection.

In this regard, it is important that Opisthorchis felineus eggs were only found in the 14 to 15th or 17 to 18th century Nadym Gorodok samples. In brief, during these periods, Nadym Gorodok people might have migrated from the Ob-Irtysh basin. In brief, Opisthorchis felineus eggs found in the 14-15th century samples might indicate the initial stage of Nadym Gorodok settlement by immigrants from the Ob-Irtysh basin, which was supported by archaeological evidence as well [18]. Then, Opisthorchis eggs found in the 17 to 18th century samples are indicative of a new stage of colonization in the $\mathrm{Ob}$ North, characterized by the construction of Russian towns by the Moscow Kingdom [16,18]. According to historical and archaeological evidences, Nadym Gorodok's residents took part in military operations across the Ob River area $[16,18,23]$. Thus, we speculate that the opisthorchiasis in Nadym Gorodok samples represents intense economic and military interactions between the residents of Nadym Gorodok and the ObIrtysh basin.

There have been no previous archaeoparasitological researches on the soil samples of the medieval settlements in arctic or subarctic Western Siberia where the indigenous population lived for centuries. Our study evidently demonstrates the presence of ancient eggs of Opisthorchis felineus, Alaria alata, and Diphyllobothrium sp. in Nadym Gorodok settlement samples, getting the detailed aspects of native West Siberian people's parasitism pattern. Based on the current results, we presume that raw or undercooked fish might have been commonly ingested by Nadym Gorodok inhabitants. It also demonstrates possible economic and military interactions between the native people and society in Western Siberia. Our study promises prospect that future archaeoparastiological studies northwestern Siberia can provide invaluable information to understand the medieval life of the native peoples of the region in a much detail.

\section{ACKNOWLEDGMENTS}

The part of the present work was funded by State Task (program XII.186.4, project No. AAAA-A17-117050400143-4 of Tyumen Scientific Center SB RAS). Partly supported by Russian Foundation for Basic Research grants 17-06-00302-A
(S.M.S., S.N.I). This work was supported by the Education and Research Encouragement Fund of Seoul National University Hospital (2019).

\section{CONFLICT OF INTEREST}

The authors declare no conflict of interest related to this study.

\section{REFERENCES}

1. Reinhard K, Slepchenko S, Shin DH. Archaeoparasitology. In Smith C ed, Encyclopedia of Global Archaeology. London, UK. Springer International Publishing. 2018, pp 1-9.

2. Reinhard KJ, Confalonieri UE, Herrmann B, Ferreira LF, Araújo A. Recovery of parasite remains from coprolites and latrines: aspects of paleoparasitological technique. Homo 1986; 37: 217239.

3. Bouchet F, Guidon N, Dittmar K, Harter S, Ferreira LF, Chaves SM, Reinhard K, Araújo A. Parasite remains in archaeological sites. Mem Inst Oswaldo Cruz 2003; 98 (suppl): 47-52.

4. Shin DH, Oh CS, Shin YM, Cho CW, Ki HC, Seo M. The pattern of ancient parasite egg contamination in the private residence, alley, ditch and streambed soils of Old Seoul City, the Capital of Joseon Dynasty. Int J Paleopathol 2013; 3: 208-213.

5. Maicher C, Hoffmann A, Côté NM, Palomo Pérez A, Saña Segui $\mathrm{M}$, Le Bailly M. Paleoparasitological investigations on the Neolithic lakeside settlement of La Draga (Lake Banyoles, Spain). Holocene 2017; 27: 1659-1668.

6. Maicher C, Bleicher N, Le Bailly M. Spatializing data in paleoparasitology: application to the study of the Neolithic lakeside settlement of Zürich-Parkhaus-Opéra, Switzerland. Holocene 2019; 29: 1198-1205.

7. Cho PY, Park JM, Hwang MK, Park SH, Park YK, Jeon BY, Kim TS, Lee HW. Discovery of parasite eggs in archeological residence during the 15th century in Seoul, Korea. Korean J Parasitol 2017; 55: 357-361.

8. Kim MJ, Seo M, Oh CS, Chai JY, Lee J, Kim GJ, Ma WY, Choi SJ, Reinhard K, Araujo A, Shin DH. Paleoparasitological study on the soil sediment samples from archaeological sites of ancient Silla Kingdom in Korean peninsula. Quat Int 2016; 405: 80-86.

9. Shin DH, Oh CS, Lee SJ, Chai JY, Kim J, Lee SD, Park JB, Choi IH, Lee HJ, Seo M. Paleo-parasitological study on the soils collected from archaeological sites in old district of Seoul City. J Archaeol Sci 2011; 38: 3555-3559.

10. Slepchenko S, Reinhard K. Paleoparasitology and pathoecology in Russia: Investigations and perspectives. Int J Paleopathol 2018; 22: 39-44.

11. Slepchenko SM, Ivanov SN, Nikolaevich BA, Alekseevich TA, Sergeyevich SV. Traditional living habits of the Taz Tundra population: a paleoparasitological study. Korean J Parasitol 2016; 54: 
617-623.

12. Slepchenko S, Kardash O, Ivanov S, Afonin A, Shin DH, Hong JH. The Buchta-Nakhodka 2 burial ground: Results of archaeoparasitological and macro-remains investigations of samples from the burial grounds of the 6th-13th century CE on the Yamal Peninsula in Russia. J Archaeol Sci Reports 2019; 23: 791799.

13. Slepchenko SM, Ivanov SN. Paleoparasitological analysis of soil samples from the Kikki-Akki burial ground of the 17th-19th centuries in West Siberia, Russia. J Archaeol Sci Reports 2015; 2: 467-472.

14. Slepchenko SM, Ivanov SN, Gusev AV, Svyatova EO, Fedorova NV. Archaeoparasitological and palynological analysis of samples from the intestinal contents of a child mummy from the Zeleniy Yar burial ground (12-13th centuries AD). Archaeol Res Asia 2019; 17: 133-136.

15. Sivkova TN, Kosintsev PA, Kardash OV. A paleoparasitological study of dog coprolites (Canis familiaris L., 1758) from the excavations of the "Nadym Gorodok" of the XVII - XVIII centuries. Bull Samara Sci Center Russian Acad Sci 2018; 20: 621-625 (in Russian).

16. Kardash OV. Nadym Gorodok. Ekaterinburg-Nefteyugansk. Moscow, Russian Federation. Magellan Publishing House. 2009, pp 360 (in Russian).

17. Vizgalov GP, Kardash AV, Kosintsev PA, Lobanova TV. Historical Ecology of the Population of the North of Western Siberia. Nefteyugansk. Moscow, Russian Federation. AMB Yekaterinburg.
2013, pp 376.

18. Kardash OV, Lips SA, Sidorova MO, Myglan VS. Nadym Gorodok: New data on the chronology and Russian development of the North of Western Siberia in the XIII - XIV centuries. Materials of All-Russian Conference "Archeology of the North of Russia: Yugra - the part of Great Novgorod in the XI-XV centuries: Code of sources and research". Surgut, Russian Federation. 2015, pp 346-381.

19. Callen EO, Cameron TWM. Aprehistoric diet revealed in coprolites. New Sci 1960; 8: 35-40.

20. Ash LR, Orihel TC. Atlas of Human Parasitology. 4th ed. Chicago, USA. American Society of Clinical Pathologists Press. 1997, pp 424.

21. Cherepanov AA, Moskvin AC, Kotelnikov GA, Khrenov VM. Atlas. Differential diagnosis of helminth infections by the morphological structure of eggs and larvae of pathogens. Moscow, Russian Federation. Russian Agricultural Academy, 2002, pp 85.

22. Beer SA. Biology of the Agent of Opisthorchiasis. Moscow, Russian Federation.Partnership of Scientific publications. 2005, pp 336.

23. Kardash OV. "100-year war" of Pustozersk and Greater Karachey XVII-XVIII centuries. (based on the results of comprehensive studies of the Pustozersky and Nadym Gorodok). Materials of All-Russian Conference "From the Time of Troubles in the Empire. New discoveries in the field of archeology and history of Russia XVI-XVIII centuries". Moscow, Russian Federation. 2016, pp 366-378. 
